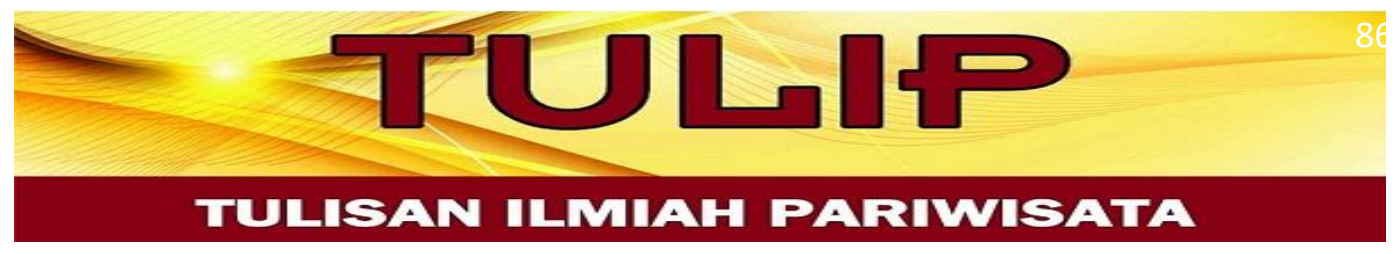

\title{
STRATEGI PENGEMBANGAN PASAR SROWOLAN SEBAGAI DAYA TARIK WISATA DI KABUPATEN SLEMAN YOGYAKARTA
}

\author{
Anggraeni M.S Lagalo \\ anggraenims@umgo.ac.id, Pariwisata,FIB_UMGo, Jl.Prof Mansoer Pateda, Indonesia
}

\begin{abstract}
Abstrak
Marketing plan yang di rancang dalam penelitian ini bertujuan sebagai pedoman stakeholder dalam menentukan langkah-langkah strategis programprogram pengembangan pasar. Pasar tradisional merupakan tempat bertemunya penjual dan pembeli serta ditandai dengan adanya transaksi penjual pembeli secara langsung dan biasanya ada proses tawar-menawar, bangunan biasanya terdiri dari kios-kios atau gerai, los dan dasaran terbuka yang dibuka oleh penjual maupun suatu pengelola pasar. Kebanyakan menjual kebutuhan seharihari seperti bahan-bahan makanan berupa ikan, buah, sayur-sayuran, telur, daging, kain, pakaian barang elektronik, jasa dan lain-lain. Selain itu, ada pula yang menjual kue-kue dan barang-barang lainnya. Pasar seperti ini masih banyak ditemukan di Indonesia, dan umumnya terletak dekat kawasan perumahan agar memudahkan pembeli untuk mencapai pasar. Beberapa pasar tradisional yang "legendaris" antara lain adalah pasar Beringharjo di Yogyakarta, pasar Klewer di Solo, pasar Johar di Semarang, serta Pasar Srowolan yang memiliki nilai sejarah perjuangan pada masa penjajahan kolonial belanda.
\end{abstract}

\section{Kata Kunci: Strategi Pengembangan;Pasar; Daya Tarik ;Wisata}

\section{A. PENDAhULUAN}

Pasar secara sederhana pasar di gambarkan sebagai tempat bertemunya penjual dan pembeli, dan terjadiya transaksi jual-beli yang memberi dampak pada pertumbuhan ekonomi masyarakat. Saat ini citra pasar tradisional mulai bergeser pada pasar yang ramah terhadap wisatawan, karena tak bisa di pungkiri banyak wisatawan yang juga ingin menyaksikan originalitas kehidupan ekonomi di pasarpasar tradisional. Oleh karenanya pasar tradional harus ramah dengan wisatawan dengan cara memperhatikan fasilitas-fasilitas umum, kebersihan dan juga keamanan. Serta memiliki daya tarik yang mampu menarik wisatawan untuk datang berkunjung.

Pasar Srowolan yang dahulunya ramai penjual dan pembeli saat ini sepi penjual dan pembeli. Hal ini disebabkan karena lemahnya aksesibilitas menuju Available Online at http://journal.umgo.ac.id/index.php/Tulip

TULIP: Tulisan Ilmiah Pariwisata, Vol.2, No. 2, Desember 2019, 86-96 


\section{TULISAN ILMIAH PARIMISATA}

Pasar Srowolan serta lemahnya daya kelola pasar sehingga menyebabkan pasar yang penuh dengan nilai sejarah ini ditinggalkan oleh penjual dan pembeli. Nilai sejarah dan budaya yang melekat pada Pasar Srowolan bisa mengembalikan eksistensinya jika pengelola pasar dalam hal ini Dinas Pasar Sleman mampu mengelola dengan baik. Diperlukan langkah-langkah strategis untuk mengembalikan eksistensi Pasar Srowolan sebagai pasar perjuangan serta menjadikannya sebagai destinasi wisata yang unggul dan mampu bersaing dengan destinasi pasar tradisional lainnya.

Pasar Srowolan yang juga dikenal sebagai Pasar Perjuangan karena pasar ini memang digunakan oleh para pejuang kemerdekaan dahulunya sebagai tempat persembunyian dan penyusunan strategi penyerangan untuk melawan penjajah. Nilai-nilai sejerah dan budaya yang ada menjadi potensi untuk menjadi sebuah destinasi wisata kuat. Agar menjadi sebuah destinasi wisata yang unggul maka perlu memperkuat PDB (positioning-differentiation-Brand) . Dampak ekonomi yang ditimbulkan jika Pasar Srowolan menjadi sebuah destinasi wisata sangat besar pengaruhnya terhadap perekenomian masyarakat yang hidup disekitar pasar ini. Presiden Obama berkata "tourism contributes to the success of American and world economies...." Industri pariwisata mampu meningkatkan perekonomian sebuah negara. Hal inilah yang terjadi di AS ketika perekonomian mereka luluh lantah akibat krisis kredit perumahan subprime mortagage, pariwisata AS turun tipih, yaitu 5\% pada periode 2008-2009 dengan angka kunjungan 54,97 juta jiwa. Setahun berikutnya sektor pariwisata menggeliat dan tumbuh $8,8 \%$ dengan total kunjungan sebanyak 59,8 juta jiwa . Penjelasan tersebut memperkuat bahwa tidak bisa dipungkiri pariwisata mampu memberi kesejahteraan masyarakat. Kesejahteraan masyarakat yang terus meningkat merupakan salah satu target pembangunan sebuah bangsa.

Berbicara relevansi kesejahteraan dan pariwisata baik dalam diskusi formal dan informal dapat ditemukan berbagai pandangan yang cukup berbeda. Dari sudut pandang para kritikus, pariwisata dinilai sebagai mesin pencerabut akar kesejaheteraan masyarakat lokal karena sering memarginalkan peran dan akses mereka dari pusaran aktivitas ekonomi yang diinduksi industri pariwisata, karena 


\section{TULISAN ILMIAH PARIMISATA}

janji-janji perluasan peluang kerja dan peningkatan kesejahteraan masyarakat dibalik pengembangan sebuah destinasi wisata dipandang sebagai sebuah gagasan yang tak kunjung direalisasi . Dikalangan birokrasi pariwisata didengungkan sebagai obat mujarab yang mampu menyulap belantara kemiskinan menjadi kemakmuran material (Janianton Damanik:2013). Pandangan ini dapat dilacak dengan muda pada visi misi pembangunan pariwisata di berbagai level, dari lokal hingga nasional. Pariwisata tentunya memberi dampak positif dan negatif pada lingkungan dan pada manusia. Oleh karenanya perlu dirumuskan design, pendekatan serta program-program yang unggul untuk mengoptimalkan kontribusi pariwisata bagi daerah destinasi. Salah satu langkah konkret yang dilakukan oleh NGO international adalah mengusung tema besar pro-poor tourism (Braman, dan FAA, 2001;Benner, et.al.,1999; Ashley dan Hayso,, 2004).

Kondisi ini menunjukkan bahwa sektor pariwisata adalah sektor yang tahan banting, karena kebutuhan liburan telah menjadi gaya hidup masyarakat. Hal inilah yang akan terjadi jika pengelolaan Pasar Srowolan di arahkan sebagai tidak hanya sebagai pasar tradisional namun juga menjadi sebuah destinasi wisata yang menawarkan kepada wisatawan nilai-nilai sejarah, budaya, serta kearifan panganan lokal dan local wisdom yang melekat di Pasar Srowolan. Namun perlu diakui bukanlah hal yang mudah untuk mencapai semua itu. Menjadi tantangan besar dan agenda pekerjaan yang sangat tidak mudah bagi para perencana pembangunan untuk menentukan keberhasilan sebuah destinasi untuk mensejahterahkan masyarakat. Misalnya saja, kompleksitas perubahan-perubahan yang terjadi dalam relasi sosial-budaya, promosi, degradasi modal sosial dan modal ekonomi serta degradasi lingkungan, potensi konflik, disparitas pendapatan, manajemen potensi konflik, partisipasi dalam perencanaan, implementasi, evaluasi dan monitoring serta distribusi tanggung jawab hasil pariwisata dalam komunitas dan seterusnya.

Langkah-langkah strategis yang ditempuh untuk menjadikan Pasar Srowolan menjadi destinasi wisata yang unggul dimulai dengan mengidentifikasi Kekuatan, Kelemahan, Peluang, dan Ancaman, atau lebih dikenal dengan istilah 


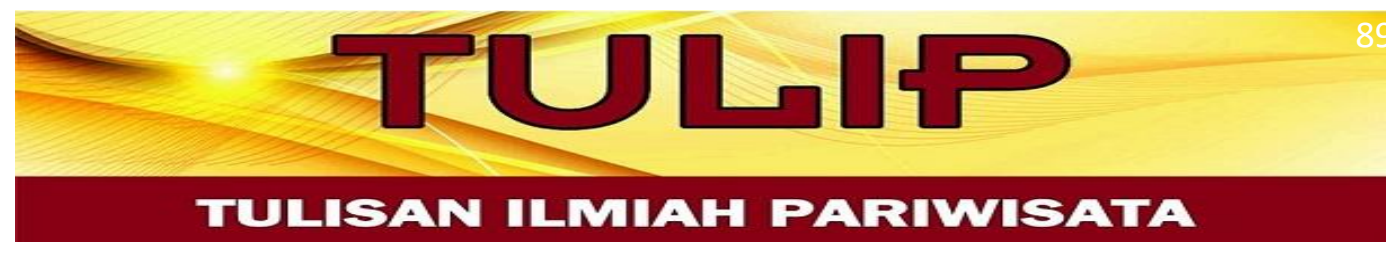

SWOT. Analisis SWOT ini akan membantu pengelola pasar untuk melakukan perencanaan bisnis wisata dari segi perencanaan, action dan evaluasi.

\section{B. HASIL DAN PEMBAHASAN}

\section{Deskripsi Pasar Srowolan}

Di Kabupaten Sleman terdapat Pasar Srowolan yang memiliki nilai histori yang tinggi. Pasar tradisional ini telah ada sejak masa penjajahan Belanda. Pasar ini merupakan saksi bisu perjuangan masyarakat melawan tentara Belanda pada saat agresi militer ke II tahun 1948. Pasar ini pernah dipugar Sri Sultan Hamengku Buwono VIII pada tahun 1921. Alasannya, pasar ini merupakan Pasar Kesultanan. Artinya, pasar ini berada di bawah administrasi Keraton Kesultanan Ngayogyakarta. Nama pasar Sorowulan berasal dari nama seorang empu wesi, yaitu Empu Aji Sorowulan, yang konon pernah hidup dan menetap di tempat ini. Di jaman perjuangan, kondisi pasar sangat ramai. Selain sebagai pasar tradisional, juga sebagai tempat pertemuan para gerilyawan. Mereka berkomunikasi dengan sesama pejuang untuk mengatur siasat melawan Belanda sekaligus belanja keperluan logistik. Para pejuang ada yang menyamar sebagai pedagang dan tukang cukur.

Kini, pasar seluas $50 \times 70$ meter ini kurang terawat. Dalam sepekan hanya sekali pasar dibuka yakni setiap Wage. Itu pun sepi pengunjung, karena kalah bersaing dengan pasar tradisional lain yang letaknya lebih strategis dan dilalui angkutan umum. Seperti Pasar Pakem, Pasar Turi, dan Pasar Sleman. Setiap Wage, penjual tidak lebih dari 5 orang. Itupun para pedagang yang sudah uzur dan tidak ada penerusnya.

Di dekat Pasar Srowolan, ada bangunan tua bekas tempat penyimpanan garam pada zaman Belanda. Letaknya, di sebelah utara Pasar Srowolan. Di dekat gudang garam, juga berdiri rumah kuno berukuran 10 x 12 meter berbentuk Sinom. Ini merupakan penanda Kecamatan Pakem Lama. Di tempat ini pulalah cikal bakal Kecamatan Pakem terbentuk. Sebelum Kecamatan Pakem terbentuk seperti sekarang, Srowolan telah berdiri sebagai kemantren. Bangunan bekas kantor kemantren itu sampai sekarang juga masih dilestarikan di tempat ini. 


\section{TULISAN ILMIAH PARIMISATA}

Berawal dari Kemantren Srowolan inilah kemudian berkembang menjadi Kecamatan Pakem. Ada satu lagi, yaitu Rumah Tinggal Sayuti Melik, penulis naskah Proklamasi Kemerdekaan. Letaknya berada di Dusun Kadisobo. Ini sangat menarik dikenalkan pada tamu wisatawan, sekaligus mengenang kembali sejarah perjuangan bangsa untuk merebut kemerdekaan. Dalam catatan Pemerintah Daerah Sleman, Pasar Srowolan adalah pasar yang dikelola UPT Pelayanan Pasar Kelompok III, dengan alamat Srowolan, Purwobinangun, Pakem, Sleman. Pasar ini berdiri diatas lahan seluas 3.737 meter persegi dengan jumlah pedagang sebanyak 11 orang.

Beruntung, masyarakat setempat masih bersemangat menghidupkan ikon Pasar Srowolan dengan menjadikan bagian dari Desa Wisata Srowolan. Desa ini merupakan satu dari 36 desa wisata di Kabupaten Sleman, Daerah Istimewa Yogyakarta (DIY). Desa Wisata Pasar Perjuangan Srowolan merupakan gabungan Pedukuhan Srowolan Gatep, Pedukuhan Karanggeneng, dan Pedukuhan Gandok Kadilobo. Ketiganya masuk Desa Purwobinangun Kecamatan Pakem, Sleman. Batas wilayah :

(1) Sebelah utara Dusun Beneran, Desa Purwobinangun

(2) Sebelah selatan Dusun Ngepas, Desa Donoharjo, Kecamatan Ngaglik

(3) Sebelah barat Dusun Gabugan Donokerto, Kecamatan Turi

(4) Sebelah timur Dusun Bunder, Purwobinangun

Pasar Srowolan yang memiliki nilai sejarah perjuangan dan kemudian sering disebut sebagai pasar perjuangan oleh masyarakat setempat perlu di kembangkan kearah pasar wisata. Rencana pengembangan ini perlu dilakukan untuk menjaga kelestarian nilai-nilai sejarah dan budaya yang ada di dalam Pasar Srowolan serta menghidupkan kegiatan ekonomi masyarakat sekitar yang memiliki profesi petani pada umumnya. Untuk itu dibutuhkan langkah-langkah strategis dan kajian yang mendalam guna mengembangkan Pasar Perjuangan ini.

\section{Analisis SWOT Pasar Srowolan}

Faktor Internal Strategi

Faktor Internal Strategi

Bobot

Rating

Skor

Terbobot 


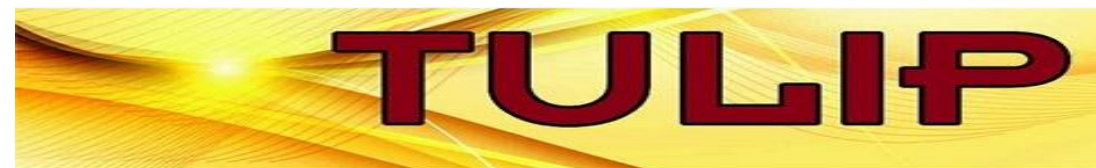

TULISAN ILMIAH PARINISATA

(a)

(b)

(axb)

\begin{tabular}{|c|c|c|c|}
\hline \multicolumn{4}{|l|}{ Kekuatan/Strength } \\
\hline $\begin{array}{l}\text { Didukung oleh keberadaan desa wisata yang } \\
\text { dekat, dua lapangan outbond, dan kerjasama } \\
\text { yang baik dengan tour agent dan ibu - ibu } \\
\text { PKK dalam pemasaran produk lokal pada } \\
\text { atraksi outbond }\end{array}$ & 0,7 & 2 & 0,14 \\
\hline $\begin{array}{l}\text { Masih ada penjual yang menjadi saksi sejarah } \\
\text { kejayaan pasar srowolan dan cerita } \\
\text { menariknya }\end{array}$ & 0,12 & 2 & 0,24 \\
\hline $\begin{array}{l}\text { Pasar perjuangan dan dimiliki oleh } \\
\text { kesultanan sehingga memiliki nilai tradisi } \\
\text { Jawa yang masih sangat kuat }\end{array}$ & 0,6 & 2 & 0,12 \\
\hline $\begin{array}{l}\text { Bangunan pasar asli dari jaman Belanda dan } \\
\text { memiliki nilai sejarah yang kuat }\end{array}$ & 0,15 & 3 & 0,45 \\
\hline $\begin{array}{l}\text { Fasilitas yang lengkap berupa toilet, lahan } \\
\text { parkir, dan direction yang jelas }\end{array}$ & 0,6 & 2 & 0,12 \\
\hline JUMLAH & $\mathbf{0 , 4 0}$ & & $\mathbf{1 , 0 7}$ \\
\hline \multicolumn{4}{|l|}{ Kelemahan/Weakness } \\
\hline Sulit akses karena jauh dari jalan utama & 0,6 & 2 & 0,12 \\
\hline Kondisi jalan setapak & 0,12 & 3 & 0,36 \\
\hline $\begin{array}{l}\text { Ketidakpedulian beberapa warga yang } \\
\text { menganggap wajar bahwa pasar srowolan } \\
\text { layak sepi karena sudah tua dan tidak } \\
\text { menarik lagi }\end{array}$ & 0,12 & 3 & 0,36 \\
\hline $\begin{array}{l}\text { Kurangnya bak sampah di sekitar lokasi } \\
\text { sehingga sampah berserakan }\end{array}$ & 0,12 & 3 & 0,36 \\
\hline $\begin{array}{l}\text { Keberadaan lahan parkir tepat di depan toilet } \\
\text { menyulitkan pengunjung dan tidak nyaman }\end{array}$ & 0,10 & 2 & 0,20 \\
\hline JUMLAH & $\mathbf{0 , 5 2}$ & & 1,40 \\
\hline TOTAL & 0,92 & & 2,47 \\
\hline
\end{tabular}

Sumber; diolah oleh peneliti dari hasil dokumentasi data lapangan 


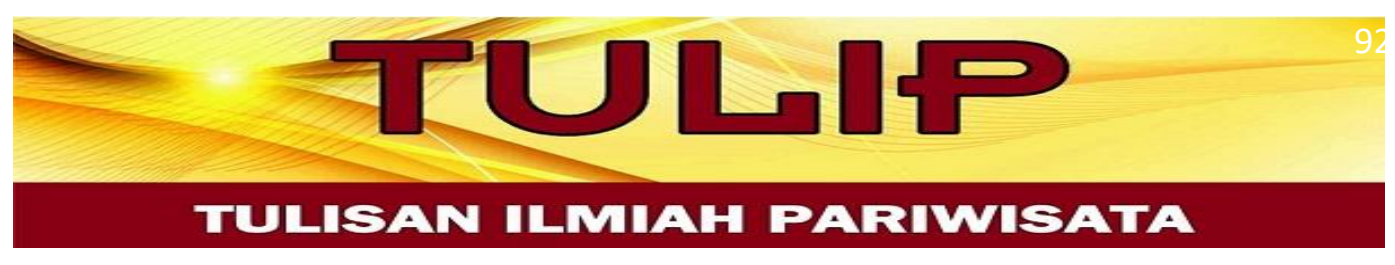

Faktor Eksternal Strategi

\begin{tabular}{|c|c|c|c|}
\hline Faktor Eksternal Strategi & $\begin{array}{l}\text { Bobot } \\
\text { (a) }\end{array}$ & $\begin{array}{l}\text { Rating } \\
\text { (b) }\end{array}$ & $\begin{array}{c}\text { Skor } \\
\text { Terbobot } \\
(\mathrm{axb}) \\
\end{array}$ \\
\hline \multicolumn{4}{|l|}{ Peluang/Opportunity } \\
\hline $\begin{array}{l}\text { Pemberdayaan petani lokal guna mampu } \\
\text { melakukan supply bahan pokok makanan } \\
\text { untuk kegiatan wisata outbond serta } \\
\text { kegiatan lainya }\end{array}$ & 0.12 & 3 & 0,36 \\
\hline $\begin{array}{l}\text { Peluang promosi wisata melalui media } \\
\text { sosial dan event-event lainnya }\end{array}$ & 0,6 & 2 & 0,12 \\
\hline $\begin{array}{l}\text { Pengembangan Pasar Srowolan sebagai } \\
\text { pasar makanan tradisional dengan target } \\
\text { market peserta outbond dan penjung desa } \\
\text { wisata }\end{array}$ & 0,18 & 3 & 0,24 \\
\hline $\begin{array}{l}\text { Kerjasama Pengelola Pasar dengan } \\
\text { outbond yang ada di dekat Pasar Srowolan }\end{array}$ & 0,18 & 4 & 0,72 \\
\hline $\begin{array}{l}\text { Pengadaan beberapa titik objek yang } \\
\text { memberikan kesempatan kepada } \\
\text { pengunjung untuk berfoto }\end{array}$ & 0,6 & 2 & 0,12 \\
\hline JUMLAH & $\mathbf{0 , 6 0}$ & & 1,56 \\
\hline \multicolumn{4}{|l|}{ Ancaman/Threathness } \\
\hline $\begin{array}{l}\text { Pengelolan pasar yang tidak berstandar dan } \\
\text { kotor }\end{array}$ & 0,6 & 2 & 0,12 \\
\hline $\begin{array}{l}\text { Pemeliharaan asset-aset pasar yang } \\
\text { bernilai sejarah tidak maksimal }\end{array}$ & 0,6 & 2 & 0,12 \\
\hline $\begin{array}{l}\text { Keberadaan pasar tradisional lainnya yang } \\
\text { memiliki aksesibilitas mumpuni dibanding } \\
\text { Pasar Srowolan }\end{array}$ & 0,12 & 3 & 0,24 \\
\hline $\begin{array}{l}\text { Lemahnya dukungan dari Pemerintah } \\
\text { Sleman }\end{array}$ & 0,6 & 3 & 0,18 \\
\hline $\begin{array}{l}\text { Berkembangnya pesaing dengan jenis } \\
\text { wisata sejenis }\end{array}$ & 0,10 & 4 & 0,40 \\
\hline JUMLAH & $\mathbf{0 , 4 0}$ & & 1,06 \\
\hline
\end{tabular}




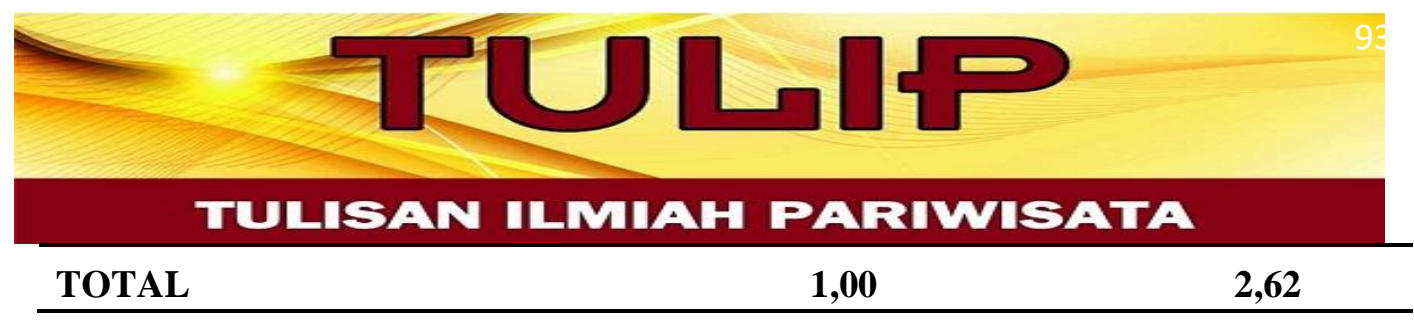

Sumber; diolah oleh peneliti dari hasil dokumentasi data lapangan

\begin{tabular}{|c|c|c|c|}
\hline \multicolumn{4}{|c|}{ Keterangan Angka } \\
\hline BOBOT & & RATING & \\
\hline $0.00-0.05$ & Tidak penting & 1 & Tidak penting \\
\hline $0.06-0.11$ & Cukup penting & 2 & Cukup penting \\
\hline $0.12-0.17$ & Penting & 3 & Penting \\
\hline $0.18-0.23$ & Penting sekali & 4 & Penting sekali \\
\hline
\end{tabular}

kelemahan pada table Internal Factor dan External Factor antara peluang dan ancaman pada table External Factor diketahui jumlah sebagai berikut:

Kekuatan $(\mathrm{S})=1,07$, Kelemahan $(\mathrm{W})=1,40$, Peluang $(\mathrm{O})=1,56$, Ancaman $(\mathrm{T})$

$=1.06$

Langkah selanjutnya adalah menentukan nilai koordinat kuadran penilaian SWOT Kali Gendol. Selisih total Kekuatan - selisih total Kelemahan $=\mathrm{S}-\mathrm{W}=\mathrm{x}$

Selisih total Peluang - selisih total Ancaman $=\mathrm{O}-\mathrm{T}=$

$\mathrm{x}=\mathrm{S}-\mathrm{W}$

$\mathrm{x}=1,07-1,40$

$\mathbf{x}=\mathbf{- 0 , 3 3}$

$\mathrm{y}=\mathrm{O}-\mathrm{T}$

Turn-around Strategy

$\mathrm{y}=1.56-1.06$

$\mathbf{y}=\mathbf{0 . 5 0}$

Weakness

Strength $(+)$

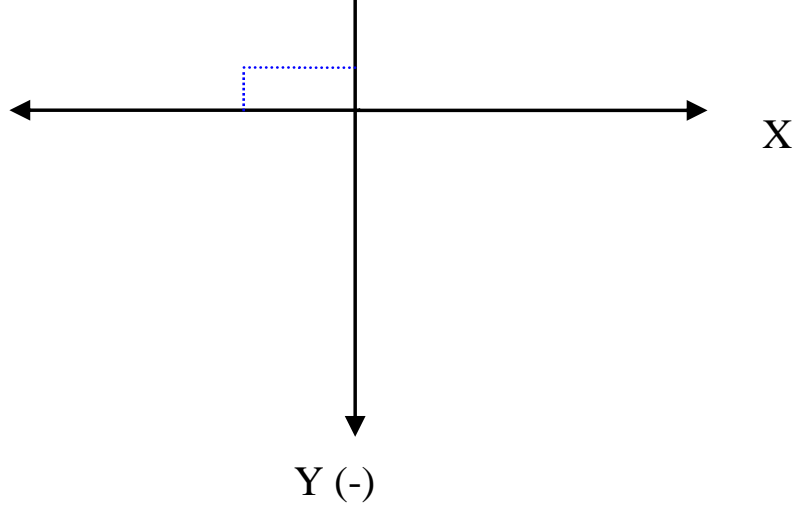

Threat

Grafik Analisis Strategi Pengembangan

Available Online at http: //journal.umgo.ac.id/index.php/Tulip

TULIP: Tulisan Ilmiah Pariwisata, Vol.2, No. 2, Desember 2019, 86-96 


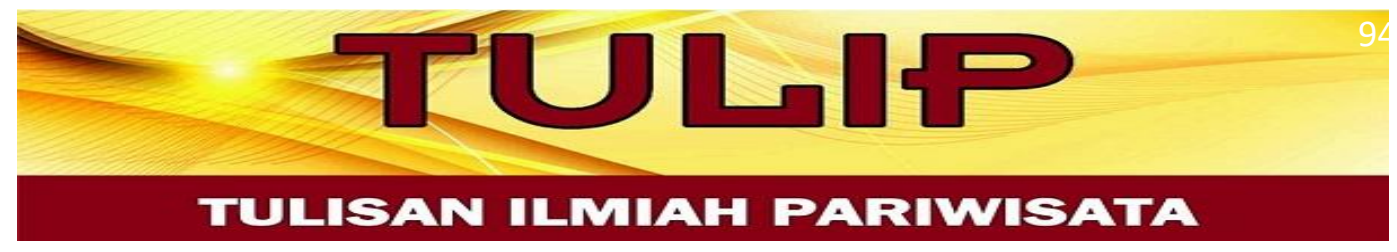

\section{Matriks Swot Pasar Srowolan Sebagai Daya Tarik Wisata}

Alat yang dipakai untuk menyusun faktor-faktor strategis pengembangan Pasar Srowolan sebagai Daya Tarik Wisata adalah Matriks SWOT. Matriks ini dapat menjelaskan secara jelas bagaimana peluang dan ancaman eksternal yang di hadapi dapat disesuaikan dengan kekuatan dan kelemahan yang dimiliki. Matriks ini menghasilkan empat set alternatif strategis :

\section{DIAGRAM MATRIKS SWOT}

\begin{tabular}{|c|c|c|}
\hline $\begin{array}{l}\text { Faktor-faktor internal } \\
\text { strategi } \\
\text { (IFAS) } \\
\text { Faktor-faktor eksternal } \\
\text { strategi } \\
\text { (EFAS) }\end{array}$ & $\begin{array}{l}\text { Strengthness } \\
\text { keberadaan desa wisata yang } \\
\text { dekat, dua lapangan outbond, } \\
\text { dan kerjasama yang baik } \\
\text { dengan tour agent dan ibu - } \\
\text { ibu PKK dalam pemasaran } \\
\text { produk lokal pada atraksi } \\
\text { outbond } \\
\text { Masih ada penjual yang } \\
\text { menjadi saksi sejarah } \\
\text { kejayaan pasar srowolan dan } \\
\text { cerita menariknya } \\
\text { - Pasar perjuangan dan } \\
\text { dimiliki oleh kesultanan } \\
\text { sehingga memiliki nilai } \\
\text { tradisi Jawa yang masih } \\
\text { sangat kuat } \\
\text { - Bangunan pasar asli dari } \\
\text { jaman Belanda dan memiliki } \\
\text { nilai sejarah yang kuat } \\
\bullet \quad \text { Fasilitas yang lengkap } \\
\text { berupa toilet, lahan parkir, } \\
\text { dan direction yang jelas }\end{array}$ & $\begin{array}{l}\text { Weakness } \\
\text { - Sulit akses karena jauh } \\
\text { dari jalan utama } \\
\text { - Kondisi jalan setapak } \\
\text { - Ketidakpedulian beberapa } \\
\text { warga yang menganggap wajar } \\
\text { bahwa pasar srowolan layak } \\
\text { sepi karena sudah tua dan tidak } \\
\text { menarik lagi } \\
\text { - Kurangnya bak sampah } \\
\text { di sekitar lokasi sehingga } \\
\text { sampah berserakan } \\
\text { - Keberadaan lahan parkir } \\
\text { tepat di depan toilet } \\
\text { menyulitkan pengunjung dan } \\
\text { tidak nyaman }\end{array}$ \\
\hline
\end{tabular}

Weakness

- Pemberdayaan petani

lokal guna mampu melakukan supply bahan pokok makanan untuk kegiatan wisata outbond serta kegiatan lainya

- Peluang promosi wisata melalui media sosial dan event-event lainnya

- Pengembangan Pasar Srowolan sebagai pasar makanan tradisional dengan 


\section{TULISAN ILMIAH PARIMISATA}

target market peserta outbond dan penjung desa wisata

- Kerjasama Pengelola Pasar dengan outbond yang ada di dekat Pasar Srowolan

- Pengadaan beberapa titik objek yang memberikan kesempatan kepada pengunjung untuk berfoto

\section{Threatness}

- Pengelolan pasar yang tidak berstandar dan kotor

- Pemeliharaan asset-aset pasar yang bernilai sejarah tidak maksimal

- Keberadaan pasar tradisional lainnya yang memiliki aksesibilitas mumpuni dibanding Pasar Srowolan

- Lemahnya dukungan dari Pemerintah Sleman

- Berkembangnya pesaing dengan jenis wisata sejenis

Sumber: Diolah oleh peneliti dari hasil dokumentasi data

\section{Kesimpulan}

Berdasarkan perhitungan kuantitatif SWOT Pasar Srowolan menandakan bahwa pengelolaan pasar ini sangat lemah namun memiliki peluang yang besar jika dikembangkan. Hasil perhitungan merujuk pada hasil Turn-around strategy (Ubah Strategi), artinya pengembangan Pasar Srowolan disarakan untuk mengubah strategi pengembangan, sebab strategi pengembangan sebelumnya sulit untuk menangkap peluang yang ada sekaligus mampu memperbaiki kinerja tata keloka Pasar Srowolan.

\section{Daftar Pustaka}

Angipora P. Marius, Dasar-dasar Pemasaran, Rajawali Pers, Jakarta, 1999

Kotler, Philip, Manajemen Pemasaran, Alih Bahasa Benjamin Molan Dan Hendra Teguh,Edisi Milenium, Jakarta, 2000.

Available Online at http: //journal.umgo.ac.id/index.php/Tulip

TULIP: Tulisan Ilmiah Pariwisata, Vol.2, No. 2, Desember 2019, 86-96 


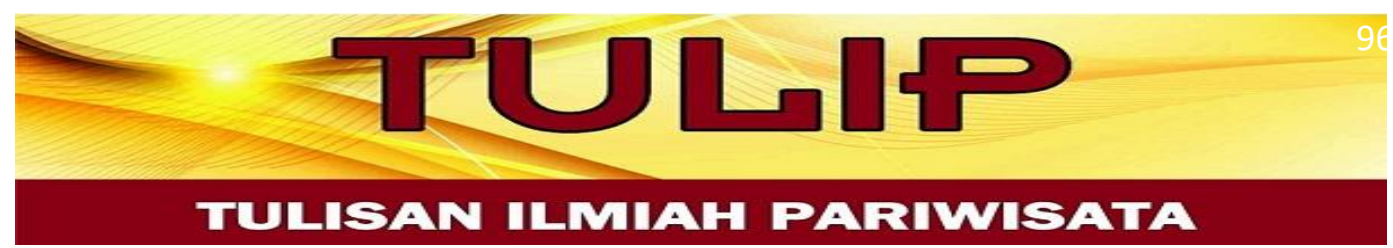

Assuari, Sofyan, Manajemen Pemasaran: Dasar, Konsep dan Strategi, Cetakan VI, PT. Raja Grafindo Persada, 1999.

Mc. Daniel, Pemasaran, Edisi I, Salemba Empat, Jakarta, 2001.

Kotler, Philip, Amstrong, G. 2008. Prinsip - Prinsip Pemasaran. Jakarta: Erlangga

Hapsari, I. 2015. Dampak Erupsi Gunung Merapi terhadap Lingkungan serta Penanganan Pasca Erupsi. Universitas Diponegoro Semarang.

Yoeti, O.A. 1997. Perencanaan dan Pengembangan Pariwisata. Jakarta: PT. Pradnya Paramita. 